\title{
Science Learning Model Based on Multisensory-Ecology in Early Childhood Education: A Conceptual Model
}

\author{
Yaswinda \\ Department of Early Childhood Education, Universitas Negeri Padang, Padang, Indonesia \\ Corresponding e-mail: yaswinda @ fip.unp
}

\begin{abstract}
In early childhood education, science learning emphasizes providing direct and real experience. That experience is needed by children in order to promote knowledge about what they see, hear, taste, touch, and smell through its five senses. Ecology-based education is needed by humans and will benefit humanity. The children interaction with environment that support will encourage children to demonstrate their learning activities. However, the authors did not found a discussion about the conceptual model of science learning based on multisensory-ecology in the books and journals. The purpose of this study was to identify a conceptual model of science learning model with based of multisensory-ecology to early childhood. The method used to develop the conceptual model included literature review and interview. The reviews of literature included academic journals, books and proceeding aimed to collect, organize and synthesize existing knowledge. Key informant interview included in-depth interviews conducted to one person's head kidergarten, four kindergarten teachers and five experts which includes an expert on science learning, expert of learning ecology, early childhood education expert, psychologists and children development expert, and instructional design expert. It can be concluded that the science learning based on multisensory-ecology of conceptual model based on multisensory-ecological for early childhood consist five characteristic and five principals of learning science learning model with based of multisensoryecology. This paper will facilitate a better conceptual understanding of learning science on early childhood education, and thereby contribute, in a small way, to the larger body of discourse surrounding it. This conceptual model will provide a reference point for education and research purposes in early childhood education. This models can be one of the guidelines for kindergarten teachers to develop basic aspects of child development, which includes cognitive, social, emotional and physical simultaneously.
\end{abstract}

Keywords: early childhood, science learning, multisensory-ecological learning, conceptual model

\section{INTRODUCTION}

Learning science is the context in which children can develop and practice basic skills. For children need encouragement from teachers to gain experience of science. That experience is needed by children to develop knowledge about what they see, hear, taste, touch through its five senses. Growing concerns about reading has strengthened almost singular focus on learning the basic skills of literacy, numeracy, and socializing. It brings the child toward increasing pressure for accountability, leaving little room for play and exploration of the world around them. In fact, children need to have the opportunity to ask and answer questions, conduct investigations, and learning to apply problem-solving skills. Children need encouragement from teachers to gain some experience science through play and interaction (NSTA position statement: early childhood science education on Science and Children, 2014). The environment of the pre-school children should provide nourishment for the children's language and overall development and that the content and their learning styles should be quite different from those of the adults (Okudo, A. R., \& Omotuyole, C. C. ,2014).

Therefore, learning in kindergarten must consider the time spent on the child as an active learner, not the subject only. All this has a lot of researchers are developing early childhood learning science, but most research has earmarked for the development of certain aspects, not integrative. While research has conduct that the use of natural ingredients to improve science process skills of kindergarten children (Muntomimah, 2014). 
Adverse effects of ecological damage are felt by almost all men. Every effort is deemed absolutely necessary in order to prevent ecological damage is not worse. The world of education was supposedly able to participate in finding a solution to the ecological damage does not destroy human life. The curriculum-based education is necessary and very important ecological turned on in every educational institution. Ecology-based education should be implemented in all levels of education (Clark, 2013).

Teachers need to consider how environmental education can be represented as a content area in the early childhood of education. Issues related to environmental education as an important emerging region in early childhood education (CutterMackenzie, A., Edwards, S., Gough, A., Gough, N., \& Whitehouse, H,2014).

In fact, children need stimulation to develop cognitive, social-emotional and physical children in an integrated learning. For that we need a model of science learning based on multisensory-ecology that can be one of the guidelines for kindergarten teachers to develop basic aspects of the child, which includes cognitive, social-emotional and physical simultaneously.

\section{LITERATURE REVIEW}

\subsection{Early Childhood Development}

Developments refers to an increase in complexity, a change from the relatively simple to the more complex and advanced. The process involves an orderly progression a long continuum. Although the sequence is basically the same for all children, the rate of acquisition can vary greatly from chid to child (Catron and Allen, 2013). Children develop at different rates. The reasons for these derivations are complex, but some of combination of genetic factors and environmental influences (Henniger, 2013).

Child development can be classified into three aspects: physical, social, emotional and cognitive (Coughlin, 1997). Berk defines cognition as an inner processes and products that lead the mind to know. It covers all mental activities such as remembering, symbolizing, categorize, problem solving, creating, fantasizing, and even dreaming. Cognitive development, then, refers to the development of thinking and reasoning abilities of children. Rogers and Ross stated social skills as the ability to judge what happens in social situations, skills to understand and correctly interpret the actions and needs of the children in group play, the ability to imagine the possible courses of action and select the one most appropriate (Brewer, 2007).

Physical development is sometimes taken for granted in early childhood. Physical development includes children's gross (large muscle) and fine (small muscle) motor skills. As young children, their muscles develop and mature. Children are able to perform more complex and refined actions. Physical development, in many ways, promotes social /emotional development (Dodge et all, 2002).

\subsection{Science Learning in Early Childhood}

Science consist of two main components, content and process. Content is the actual body of knowledge developed over time by the scientific community. The example of science content is the study about of plants. The scientific process, often referred of method and attitudes used by scientists to get information of knowledge and solve problems (Henniger, 2013). Three categories that the contents of science: (1) earth and the environment: learning about shadow, water, rock, sand, how take care the environment and take care of the world aroud (2) life science: the topic about plant, animal, and human body health, and (3) physical science: learning about properties of objects such as shape, weight, size, color, temperature, et all (Dodge, et all ,2002).

According Henniger (2013), the contents of science includes: physical science (physics and chemistry), life science (zoology and botany), earth and space science (geology and atronomy). The science curriculum content for young children responds to their need to learn about the world around them. The content of science for early children is a discover concepts, scientific reasoning, the nature of science, and doing science. It is not primarily a science of information. While facts are important, children need to begin to build an understanding of basic concepts and how they connect to the world in which they live.

In the early childhood years, scientific processes are the ways children seek answers to their questions. young children can encourage in various science processes by observing, describing, comparing, questioning, colecting and organizing data, communicating with others, interpreting results, and seeking answers to question (Hoom, 2007). Claudia and Loa (2008) said, that what is needed is an integrated science curriculum, which uses hands-on learning activities and experiences. It can be concluded conceptual science learning is learning a combination of process skills and content 
through various methods and approaches to develop cognitive, social-emotional and physical them.

\subsection{The Multisensory Experience}

Sensory is the process of detecting the presence of stimuli from the outside environment through the senses. The sensory system is important in human life. In humans, there are five sensory systems: (1) visual system; (2) auditory; (3) somatosensory; (4) olfactory; and (5) gustatory (Puspita, et all, 2012). Without this ability, people will find it difficult to activate the ability to think. Information received and disbursed senses empowering people to develop ideas, organize action, and manage the emotions of the environment. The impact of early experience in the construction and function of the brain has a large influence on the social and emotional development.

Move the resulting individual is also derived from the cognitive processes that occur in the motor cortex and reflexive activity in the central nervous system (Gallahue, 1989). So, the ability of cognitive, social, emotional and physical are intertwined and inseparable. Multisensory processing is defined as the influence of one sensory modality on activity generated by another modality. However, for most of its history, the term "multisensory" had been synonymous with the term "bimodal" (describing a neuron that can be activated by the independent presentation of stimuli from more than one modality (Fox and Schirrmacher, 2012).

\subsection{Study of Ecology in Early Childhood}

Ecology is the study of living things in relation to their environment and to one another. The environment, thing that surrounds us. we human beings change the environment with our actions and reactions. In addition, everything in nature is constantly changing, and change in one area can cause changes in another. There are several approaches you can take in your early childhood curriculum planning that will include the changing environment and what we can do to protect it. (Jackman, 2012).

Ecology is the study of relationships between organisms and their environment, including the physical and chemical and biological components or the surrounding living beings. This relationship includes interactions with the physical world as well as with the members and the same or different species. (Smith and Smit, 2009). Ecology is the study of all elements of an environment, both living and non-living and the interrelation of these elements. The term comes from two Greek words: ecos, meaning the "place to live" or "home," and ology, meaning "study of"“. If we stop to consider our work with young children, we have probably touched on the subject of ecology frequently. For example,' we-notice the changes in the weather and discuss how these affect plants, birds, animals, and ourselves. When love plant seeds, hatch eggs, or care for a pet, we notice those things that are necessary for life and grow. (Mayesky, 2012).

\subsection{Learning Model in Kindergarten}

The learning model is defined as a pattern that describes the details of the environmental situation which allows children to interact in the learning process so that there is a development or change (Mulyasa, 2012). According to Joyce, et al (2009), a model of teaching as well be learning model is a plan teaching showing learning patterns resulting in the learning process to help students to get information, ideas, skills, values, thinking skills, and can self-actualization. Keywords need to be understood in a learning model are: (1) syntax; (2) the social system; (3) reaction principle; (4) support systems; and (5) the effect of learning objectives and purposes.

Integrated learning by Collin and Hazel is a form of learning that combines authentic events through a selection of themes that encourage children's curiosity to solve the problem through the approach of exploration or investigation. Interest in learning assessment kindergartens provide useful information about the learning and developmental stage of children for teachers who provide the program. Assessment involves intelligent observation of children by adults who are experienced and knowledgeable about the purpose of improving the program. Assessment and evaluation are designed to provide feedback on the effectiveness of the program and the achievement of learning outcomes (Lachlan, et.all). 


\section{METHODOLOGICAL}

The method used to develop the conceptual model included literature review and key informant interview. The reviews of literature included academic journals, books and case studies aimed to collect, organize and synthesize existing knowledge about: theory of model learning, learning science on early childhood education, multisensory experience, multisensory learning, learning based on ecology, and children development. The selected references were then analysed. We used the reviewed literature to develop the criteria for determining the learning science and early childhood development. The information requirements are the objects on the conceptual model.

Key informant interview included in-depth interviews conducted to one person's head kindergarten and five experts. Based on interviews with the head of kindergarten Aisyiyah Bustanul Athfal 86 Filtrasi science learning has become a part of learning in kindergarten with learning in the centre of the room. Children learn science based planning that made teachers adapted to the theme, but learning science does not measure simultaneously measuring the development of cognitive, social, emotional and physical. Science learning more priority to children's cognitive development by using worksheets and rarely do science experiments. Based on the literature study and interviews with the head of the kindergarten, designed a conceptual model of science learning by multisensory-ecology s ready to be validated by experts.

The experts which includes an expert on science learning, expert of learning ecology, early childhood education experts, psychologists and children development, and instructional design experts as validator. Validation techniques used by interviewing experts. Expert validation is done by giving written documents to five experts. The conceptual model is validated in the form of books as teaching materials designed a model science learning on early childhood. At the time of execution made written tranship. Expert feedback is quite positive, they praised the systematic models, there is little revision use the right words. Based on the input and evaluation experts, the model was revised.

\section{FINDING AND DISCUSION}

\subsection{Finding}

The conceptual model components are divided into three main categories: input, process and output. The input is early childhood abilities and our desired output is improved the performance. The process/intervention between the input and output is the process of learning science based on multisensory-ecological. The finding in research are a conceptual model show in figure 1 .

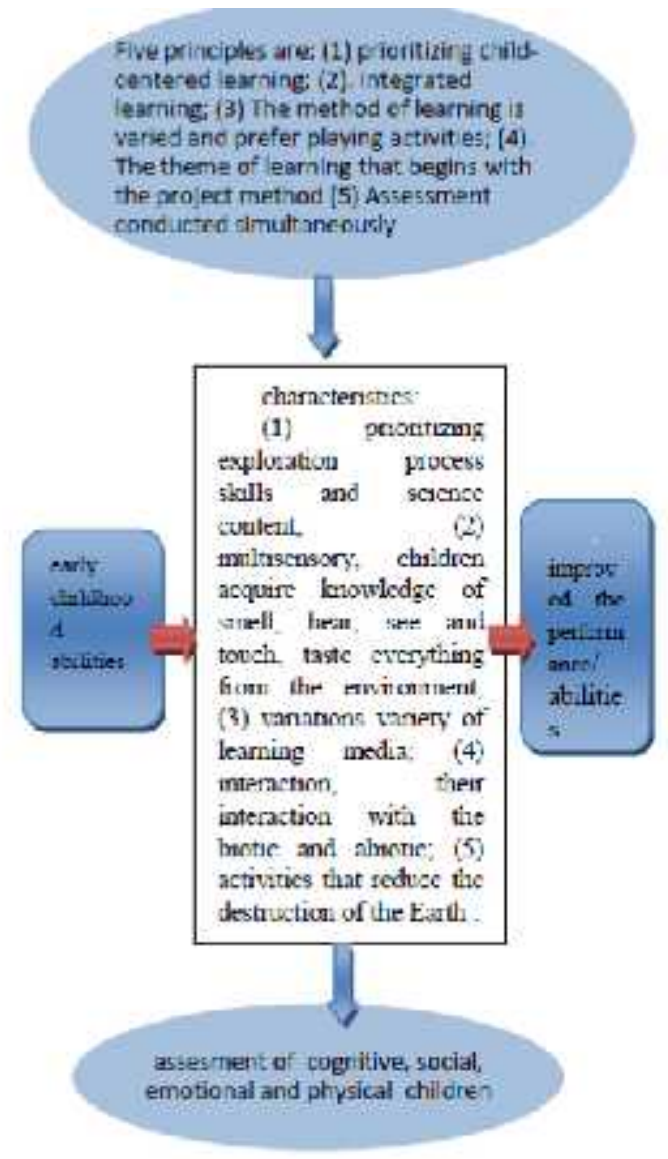

Figure 1. A Conceptual Model of Science Learning Based on Multisensory-Ecology for Early Childhood

Multisensory-ecology based science learning model for early childhood, which are at the age of kindergarten can be developed systematically based on the study of theories of child development, learning in kindergarten and learning science and early childhood based multisensory-ecology. The conceptual design multisensory learning model based science of ecology for children of kindergarten which consists of components that constitute a system. Stages in this conceptual model systems multisensory-ecology based science learning can be described as follows:

1. The model begins by looking at the child as a subject that requires learning extracted from theories of child development. This development includes 
three main aspects of the development of cognitive, social emotional and physical.

2. Children who are future growth and development of thinking, not only with one of the senses, because multisensory teaching techniques provide space for children to learn actively (active learning) from the source environment and other environments that support will encourage children to show learning activities. Multisensory learning program based science-ecology conducted in kindergarten based learning in kindergarten with learning principles: (1) The child-centred learning; (2). Integrated learning; (3) The method of learning is varied and prefer playing activities; (4). The theme of learning that begins with the project method (5) Assessment conducted simultaneously in the learning process for developing cognitive, social-emotional and physical. 3. Learning science-based multisensory-ecological derived from the theory of the science of early childhood learning, learning theory and the theory of multisensory experience-based learning ecology consists of four main content science learning related to biology, physics, earth and the universe and environment-based multisensory-ecology. The most important thing is a multisensory experiencebased learning and ecology should be implemented in every process of science learning activities with the following characteristics: (1) prioritizing exploration process skills and science content; (2) multisensory, children acquire knowledge of feeling, smell, hear, see and feel everything from the environment; (3) variations variety of learning media; (4) interaction, their interaction with the biotic (living organisms) and abiotic; and (5) activities that reduce the destruction of the Earth (use of waste materials, natural materials, or materials used)

4. The learning process multisensory-ecological science can be observed through the syntax learning model that consists of four main phases, namely: (1). Pre-of learning (2) Introduction, (3); Learning the form of activities undertaken to achieve the objectives of the materials studied is composed of a core learning activity phase, frequently asked questions, strengthening the understanding and setting trash; and (4). Closing

5. Development of the theme in this case includes learning objectives, learning methods, media and learning resources are used, how the process sequence of learning activities carried out as well as the allocation of instructional time.

6 . The assessment was conducted throughout the process of the activity. Aspects observed are aspects of cognitive, social emotional and physical. 7.

Outcome of multisensory learning-based science of ecology is expected an increase in cognitive ability, social-emotional and physical

\subsection{Discussion}

Early children are naturally curious and constantly exploring the world around them. Classroom science provides the opportunity for children to extend this natural curiosity and building of concept about things. By Science exploration in early childhood, they can inquiry - exploring materials, asking questions, investigating, recording their work, reflecting on what they have done. Science has an important role to play in helping respond to complex social problems, including those affecting children. Science exploration can develop sensory, physical, social-emotional, and cognition.

The importance of learning science for young children is to convey to the child that to understand the world or the surrounding environment through a process known as scientific investigation. Child observes with all their senses and to classify, predict, and communicate, so that they can find another viewpoint. For that science learning is done in an integrated learning as he has done (Backshall 2014), using a base of free play for children aged 3-5 years. Learning science can also be viewed from the perspective of local culture (Fleer, Gomes and March, 2014). The teacher should use approaches, strategies and methods are appropriate. Shozo Fukodo study that recommends science learning early childhood learning model Reggio Emilia for learning covers a wide range of scientific concepts. This learning has some characteristics of a childcentered approach and integrated learning (Fukodo, 2014).

Learning science in early childhood education needed is an integrated science curriculum, which uses hands-on learning activities and experiences. It can be concluded conceptual science learning is learning a combination of process skills and content through various methods and approaches to develop cognitive, social-emotional and physical them. So, it, Early childhood science learning is a program that supports children's learning environment exploration around children by emphasizing skills such processes (1) to observe; (2) comparing; (3) sort; (4) classifying, (5) predict; and (6) communicate with content of the introduction of the concept of science that deals with the phenomenon.

Multisensory field experience is the starting point to learn concrete and developmentally appropriate. For that children need encouragement from the environment to experience science through scientific discovery and multisensory activities. With no way to get experience early science experiments meant to make children less than optimal in the study of science itself 


\section{CONCLUSIONS}

It can be concluded that the learning of sciencebased multisensory-ecology is learning that prioritizes process skills and content of science through experience multisensory (activities that involve the senses of sight, hearing, feeling, smelling and tasting) and of the importance of human interaction with the environment in an integrated learning with the aim improve cognitive abilities, social, emotional and physical early childhood with five characteristics and the five principles of learning.

Five characteristics model, are: (1) prioritizing exploration process skills and science content; (2) multisensory, children acquire knowledge of feeling, smell, hear, see and feel everything from the environment; (3) variations variety of learning media; (4) interaction, their interaction with the biotic (living organisms) and abiotic; and (5) activities that reduce the destruction of the Earth (use of waste materials, natural materials, or materials used).

This paper will facilitate a better conceptual understanding of learning science on early childhood education. This conceptual model will provide a reference point for education and research purposes in early childhood education. This models can be one of the guidelines for kindergarten teachers to develop basic aspects of child development, which includes cognitive, social, emotional and physical simultaneously.

\section{ACKNOWLEDGEMENTS}

In this moment I would like to thank Mrs. Prof. Dr.Yufiarti, M.Psi and Prof. Dr. Atwi Suparman, M.Sc. Financial support from the Kemenristekdikti Indonesian very helpful publication of this article.

\section{REFERENCES}

Backshall, B, (2014) Science Education in Harmony With a Holistic Play Based Curriculum in New Zealand in the Proceedings PICERA, Bali: PICERA

Brewer,J.A (2007). Early Childhood Education, Preschool Throught Primary Grades, Sixth Edition. Boston : Pearson,

Catron, C E. and Allen, J. (2003) Early Childhood Curriculum, A Creative Play Model, Second Edition. New Jersey : Prentice-Hall, Inc.

Coughlin, P (1997) Creating a Class That Centered on Children, Jakarta: Indonesia CRI, p.24.

Cutter-Mackenzie, A., Edwards, S., Gough, A., Gough, N., \& Whitehouse, H. (2014).

Everyday environmental education experiences: The role of content in early childhood education. Australian Journal of Environmental Education, 30(1), 127-133. doi:http://dx.doi.org/10.1017/ aee.2014.37

Dodge,L Colker, J dan Heroman, C (2002), The Creative Curriculum For preschool. Fourth Edition. Washington: Teaching Strategies.

Eliason, C and Loa, J (2008), A Practical Guide to early Childhood Curriculum, Eight Edition, New Jersey: Pearson.

Fleer,M. Gomes, J and March,S. (2014) Science learning affordances in preschool environments, in the Australasian Journal of Early Childhood. 39.1: p. 38 http: // www. earlychildhoodaustralia. org.au/australian

Fox,J.E and Scirrmacher,R (2012). Art \& Creative Development for Young Children. 7 th Edition. China : Wadsworth Cengage learning,

Fukodo, S. (2014) Reggio Emilia Way of Science Education for Young Children, Proceedings of the Living in Harmony throught Early Childhood Education Early Childhood Education \& Care, Bali: PICERA, p, 138.

Gallahue,D.L (1989), Understanding Motor Development : Infants, Children, Adolescents, Indiana : Benchmark Press, Inc, p. 16

Henniger, M.L (2013). Teaching Young Children An Introduction, 5th Edition, Boston : Pearson.

Hoorn,J.V etc (2007). Play at the Cenrter of the Curriculum, Fourth Edition, New Jersey: Pearson Printece Hall

Jackman, H.L., (2012). Early Education Curriculum, A Child Connection to The World . Fifth Edition, Wadsworth: Cencage learning.

Joyce,B,. Weil,M and Calhoun, E (2009). Models of Teaching. Boston: Pearson

Clark, K.E, (2013). Ecologigal Intelegence and Sustainability Education in Special Education Multicultural Education, 21.1) p. 38, http : //www. Caddogap.com.

Mulyasa, H.E, (2012) Management Educatinal. Bandung: PT Youth Rosdakarya .

Mayesky (2012). Creative Activites for Young Children, 10th Edition. Wasworth, Cengage Learning.

Muntomimah, Early Childhood Education Journal, Volume 8 Issue 1, April 2014, (Jakarta: PPS UNJ, 2014) p. 73-164

Puspita,I, Indri, I,. Hapsarii, Suryaratri, R.D.,(2012) Psychology Faal, Psychology and Psysiology Review in understanding human behavior, Bandung: PT Youth Rosdakarya, p. 108.

Okudo, A. R., \& Omotuyole, C. C. (2014). ENHANCED LEARNING ENVIRONMENT AND ITS IMPLICATIONS ON THE PRESCHOOL CHILDREN'S LANGUAGE PERFORMANCE. European Scientific 
Journal, 10(7) Retrieved from

http://search.proquest.com

/docview/1524986722? accountid=38628

Sari, Nuryadin, and Sujiono. Early Childhood

Education, Volume 8 Issue 1, April 2014,

Jakarta: PPS UNJ, 2014.

Smith, TM and Smith,R..L (2009). Elements of

Ecology, Seventh Edition, San Fransisco:

Pearson Education 